\section{Stations in space}

International partners in the US space station are signing up years before they should.

THE space station on whose construction the US National Aeronautics and Space Administration (NASA) is embarking will soon be fully provided for except in one respect - a purpose. At the outset, the intended overseas partners (Canada, the European Space Agency or ESA and Japan) should have formally undertaken their obligations more than a year ago, but that hope was postponed by the row over what the US Department of Defense would require of the space station, while the need for agreement was diminished by the prolonged grounding of the shuttle. Only now are the documents being signed and sealed (see page 293). And while some grown men and women will now sleep easier in their beds, knowing that one hurdle lies behind them, others involved in the long negotiations, chiefly from the partner delegations, will sleep less easily while asking to what they have committed their governments.

The row about the interest of the Department of Defense, which dates from the end of 1986, has been a red herring. From the start, the Pentagon made no secret of its wish to follow the development of the space station (some parts of which may be in place by 1993) with the intention of using it for carrying out experiments if that should seem prudent. The pace of the development of the Strategic Defense Initiative (SDI) at the end of 1986 naturally prompted the Pentagon formally to ask NASA to keep its interests in mind while negotiating the terms on which overseas partners would participate. At least one of the potential partners saw this as an opportunity to withdraw with honour, on the grounds that it had no brief from its electors to sponsor SDI research. In the event, NASA diplomacy has plainly won the day, keeping its partners sweet while leaving the Pentagon's interest intact. Time will tell whether the doubters would have been better served if they had simply asked what the whole enterprise is for.

Nothing is more eloquent of the long planning delays preceeding innovations of technology in space, and of the way in which they necessarily embody ambitions belonging to an era past, than the space station as now conceived. Its roots lie in the period when it seemed as if the US space station had become just another means of transport, as if it were a kind of motor-car, and when NASA was casting around for other things to do. Reports of Soviet achievements with Soyuz spacecraft came thick and fast (as they still do) in 1984 and 1985, with the result that NASA naturally turned to emulation.

With the passage of time, two things have happened. First, ingenious people have devised ingenious uses to which a habitable space station might be put. The opportunities of microgravity (when thermal convection is suppressed) for fabricating pure crystals or separating materials cleanly by electrophoresis are so well canvassed that honest observers must often ask whether SDI does not have a better case. The plain truth is that the space station exists, if only as a concept now, because four and three years ago it seemed the natural next exploit. Unsurprisingly, it has been overtaken by events. Not only has there been the Challenger accident, but the United States has formally declared its aspirations towards even more ambitious goals in space - the inhabited base on the Moon and, sometime early next century, the trip to Mars. NASA may say that, providentially, the space station is just the means that a farsighted person would have devised for getting to those distant places, but talk like that cuts no ice elsewhere.

The tragedy of the space station, as now conceived and voted for by participating governments elsewhere, is that it emphasizes the emptiness of fashionable interests in the exploration of space. It is not as if there is nothing else to do. When the Hubble Space Telescope is eventually launched (it should have been a going concern for at least a year), our knowledge and under- standing of the Universe will be increased as much as it has been since Galileo's time: is that not a prize worth winning? Might it not be worthwhile, even at this poignant time when the shuttle is still on the ground, to build a second version in case the first should fail? Others will naturally have different but equally sustainable opinions of how the resources might be better spent on other ventures beyond the atmosphere.

More mundane considerations also obtrude. The cost of building the space station will be large, but not huge. The total cost will be roughly ten per cent of the annual federal deficit, but spread out over nearly a decade. Moreover, as NASA has always said, the money will not leave the ground, but will stay on the surface of the Earth, creating jobs and augmenting economic activity.

The flaw in that argument is that a country such as the United States, which has stumbled into the dubious role of the world's largest debtor, would ordinarily be compelled by economic necessity to persuade its creditors that it is a prudent manager of its own affairs. In the circumstances, may it not be particularly tactless that it should have set out to persuade its creditors to join in the folly? It is as if a man on the edge of bankruptcy tempted his bank-manager to the races for the afternoon.

\section{Living with civil war}

\section{This week's roster of assasination may, with luck, be enough to turn assasins' stomachs.}

THE past few days have been shoddy times for the notion that the first element of freedom is that one's life will not wantonly be taken away. True, the Supreme Court of the Republic of South Africa has allowed that six people taken apparently at random from a murderous (and murdering) mob should have a stay of execution pending a retrial. But an Israeli conscript has been killed in Bethlehem, as have been more than a score of Palestinians in the West Bank during the past month, while we still have to learn with certainty what went on in Azerbajian. Violence, as thay used to say in the musical play Oklahoma, seems to be breaking out all over.

No more so than in Ireland, where the concept of death has been exquisitely refined (James Joyce's prose poem The Dead refers): if to die in a good cause is to be assured of a place in other peoples' memories, and perhaps even of immortality, if not literally then in the jungian sense (of the collective unconscious), may it not have been rational that the mourners at last Saturday's funeral in Belfast should have murdered the two soldiers who appear to have blundered into their way? What does it matter that two young people should have been, for the time being, denied the chance to chat up their friends?

The English, a subset of the British, do not understand the Irish notion of death, which is probably why a group of British soldiers considered that it made sense to kill rather than arrest three Irish people (one a woman) in Gibralter two weeks ago, on suspicion (probably well founded) of planning to explode a bomb. Clinically, killing would have made the problem go away; in reality, it has ensured its persistence.

What happens now if the British government discovers there is no way out but the rule of law? Then there will be civil war in Ulster, not for the first time. Emollient devices, such as better housing or education, are no longer sufficiently immediate. Nor are schemes for pumping money into job-creation. Naturally, it would help if those people who vote in Britain and whose energies are spent battling apartheid in distant South Africa were to lend them to this more urgent cause. Almost certainly, that is asking too much. The discomfitting characteristic of domestic civil war is that it is uncomfortable; easier to fight somebody else's. Yet events are at such a pass that it may be permissible to hope that people will have been so sobered by what they have done that they acknowledge they have no choice but to find a better way to a different world. 